\title{
Hydrological Analysis of TRMM (Tropical Rainfall Measuring Mission) Data in Lesti Sub Watershed
}

\author{
Suryaningtyas Lufi ${ }^{1}$, Suhartanto Ery ${ }^{2}$, Rispiningtati ${ }^{2}$ \\ ${ }^{1}$ Hydrology Department, PT Saka Buana Yasa Selaras, Banjarmasin, 70236, Indonesia \\ ${ }^{2}$ Water Resources Engineering Department, Universitas Brawijaya, Malang, 65145, \\ Indonesia \\ lufisuryaningtyas@gmail.com
}

Received 19-12-2019; accepted 02-03-2020

\begin{abstract}
Alternative solution for availability of inadequate rain data as input to hydrological data is with the assist of Tropical Rainfall Measurement Mission (TRMM) satellite rainfall data which using remote sensing technology (satellite). The purpose of this study is to look for correlations and data corrections and validate TRMM satellite data with rainfall data at the rain station and discharge observation data. Lesti sub-watershed is used as a case study with consideration of the data availability that is considered sufficient. The validation results of corrected TRMM rain data produce Nash-Sutcliffe Efficiency (NSE), Root Mean Squared Error (RMSE), Correlation Coefficient (R), and Relative Error (KR). Then, conducted an analysis of the flow discharge estimation using TRMM rainfall data and validated with Tawangrejeni Automatic Water Level Record (AWLR) data. The results of flow discharge validation using the FJ Mock Method produce an NSE value of 0.507, RMSE 19.383, Correlation Coefficient (R) 0.713 , and Relative Error of 0.001. Overall analysis shows TRMM data can be used as an alternative of the rain data that is used to estimate flow discharge, but the result of flow discharge analysis is still better using rainfall data from the rain station post.
\end{abstract}

Keywords: rainfall, TRMM, rain station post, validation, flow discharge, FJ Mock

\section{Introduction}

The rainfall data information is very important for various analyzes of water resources. Rainfall data can be in the form of temporal (time series) or spatial [9]. As one of the important data in hydrological analysis, rainfall data obtained from measurements at the rain station post, so that the rainfall data obtained are expected to have sufficient accuracy.

Rainfall data in time series recording can provide trend information from the nature of rain in a place whether it has increased or vice versa. From this description can be said that rainfall data is climatological data that is quite important. Accurate and timely observations and estimates of regional and global precipitation are crucial for various researches and applications [6].

Cite this as: Suryaningtyas, L., Ery, S., \& Rispiningtati, R. (2020). Hydrological Analysis of TRMM (Tropical Rainfall Measuring Mission) Data in Lesti Sub Watershed. Civil and Environmental Science Journal, 3(1), pp.18-30. doi: https://doi.org/10.21776/ub.civense.2020.00301.3 
In fact to obtain the representative rainfall observation data namely both in terms of quality and quantity or length of its observation data that quite appropriate with the requirements is very difficult. The difficulty to get rainfall data, due to the limited number of measuring devices or gauge especially in remote areas, so that it will be difficult to conduct studies and analysis of water resources based on rainfall data in a place because not all places have rainfall monitoring stations manually or automatically [8].

According to Syaifullah [9], the latest technological development, namely in the form of satellite technology (remote sensing) is able to make a breakthrough in terms of the acquisition of rainfall information (precipitation) because with remote sensing technology now has been able to conduct precipitation measurement from remote distance. Areas that do not have sufficient rain recording stations are almost impossible to measure rainfall, but with this technology it is possible to obtain precipitation data that is not limited in space and time, so that it can simply be said that with satellite technology rainfall data can be obtained anytime and anywhere.

Tropical Rainfall Measuring Mission (TRMM) satellite has achieved some research progress since its launch in 1997 [1]. TRMM satellite was launched in November 1997 and has been producing since 1998 [3]. One of the satellite technology that has been developed is the TRMM meteorological satellite, which has two types of data namely TRMM NASA (3B42RT) developed by National Aeronautics and Space Administration and TRMM Jaxa (GSMap_NRT) developed by Japan Aerospace Exploration Agency (JAXA), which its results in the form of rainfall data (precipitation) that occurs in the atmosphere with a certain spatial resolution and within period of 3 hours, daily or monthly [9].

Considering that, then it is necessary to conduct evaluation whether the rainfall data from the TRMM satellite and from the existing rain station post network will produce maximum information so that can be obtained the magnitude of rainfall at all points with sufficient accuracy or even differ greatly. In the Lesti Sub Watershed with an area of $381,21 \mathrm{~km}^{2}$ and has five closest rain stations with the uneven position of the rain station post.

This study will examine how the correlation of the rainfall station post data towards the satellite rainfall data. This analysis is carried out in an effort to get the value of correlation and accuracy in the results of the analysis of flow discharge estimation using rainfall data at the observation station and satellite rainfall.

\section{Materials and Methods}

\subsection{Materials}

Data needed for this analysis, namely data of rain station coordinate, DEM, topographic map and river network map, daily rainfall data from the 5 closest rain stations in the Lesti Sub-Watershed for 17 years (2002-2018), TRMM rainfall data per 3 hours (TRMM_3B42RT v7), Tawangrejeni AWLR discharge data for 12 years (2007-2018), and Lesti Sub Watershed land use data.

\subsection{Method}

\subsubsection{Hydrological Analysis \\ Consistency Test}

Data consistency test is carried out to find out whether there is any deviation in the available rainfall data, so that it can be known whether the data is suitable to be used in further hydrological analysis or not. In this study 2 (two) methods were performed, namely (1) double mass curves; (2) Rescaled Adjusted Partial Sums (RAPS) [7].

\section{Homogeneity Test}

A series of hydrological data that is presented chronologically as a function of the same time is called a periodic series. The field data that published in general are discharge data, rainfall data, and others. Data is arranged in a series of periodic forms, so that before used for further analysis must be tested. 
The data testing intended are: (1) Test for No Trend; (2) Stationary Test; (3) Persistence Test. The three stages of testing are often referred to as data filtering.

\subsubsection{Thiessen Polygon Method}

Rain station post rainfall data that will be used in the form of regional average rainfall data which calculated using the Thiessen Polygon Method.

\subsubsection{TRMM Rainfall Data Validation Test}

For validation test, using the method of Nash-Sutcliffe Efficiency (NSE), Correlation coefficient (R), Root Mean Squared Error (RMSE), and Relative Error (RE). There are two validation analysis performed, namely validation of uncorrected TRMM data and validation of corrected TRMM data [5].

Validation of uncorrected TRMM data using rain station post rainfall data and uncorrected TRMM. The periods used are monthly with a data length of 7 years (2011-2018), 4 years (2014-2018), 1 year (2018).

As for the corrected TRMM data validation conducted a number of processes first, namely calibration, verification, and validation. Calibration and verification using the scatter plot method. For calibration used monthly periods with data length of 10 years (2002-2011), 13 years (2002-2014) and 16 years (2002-2017). While the verification and validation test uses a monthly period with a data length of 7 years (2011-2018), 4 years (2014-2018), 1 year (2018), excluding calibration years.

\subsubsection{Analysis of Rain Data into Flow Discharge with F.J. Mock Method}

Analysis of rainfall data into flow discharge in this study uses the Mock Method which in principle takes into account water balance above the surface and water balance in the ground (groundwater) which is affected by rain, soil type and climate $[2,4]$.

As for the data used in the flow discharge analysis using the FJ Mock Method, among others:

1. Results of the Regional Average Rainfall Analysis in Lesti Sub Watershed in 2007 - 2008

2. TRMM Rainfall Data before being corrected and after being corrected in 2007-2018

3. Tawangrejeni AWLR discharge recording data for 2007-2018

4. Data on climate recording at Karangploso Climatology Station in 2007-2018, as for the measured data needed are :

$\mathrm{t}=$ monthly average temperature $\left({ }^{\circ} \mathrm{C}\right)$

$\mathrm{RH} \quad=$ monthly average relative humidity $(\%)$

$\mathrm{n} / \mathrm{N} \quad=$ monthly sun brightness $(\%)$

$\mathrm{u} \quad=$ monthly average wind speed $(\mathrm{m} / \mathrm{sec})$

5. Coordinate data of the observation point namely the point where AWLR Tawangrejeni is located. $\mathrm{LL}=$ Latitude Location of location being reviewed

6. The initial storage value is obtained by trial and error

7. The initial groundwater storage value is obtained by trial and error

After obtaining the F.J Mock discharge value with the rain station post data, TRMM before and after corrected, the discharge data is analyzed its validation with AWLR discharge data using the method of Nash-Sutcliffe Efficiency (NSE), Correlation Coefficient (R), Root Mean Squared Error (RMSE), and Relative Error (RE).

As for the validation method formula used in this study, namely:

\section{Nash-Sutcliffe Efficiency (NSE)}

This method shows how well the plot of the observation value (measurement) is compared to the prediction-simulation value, according to the 1: 1 line, with a range of values $\infty$ to 1 . In other words, the closer to 1 , then the better the NSE value. 


$$
\mathrm{NSE}=1-\frac{\sum_{i=1}^{N}\left(X_{i}-Y_{i}\right)^{2}}{\left(X_{i}-\bar{X}_{i}\right)^{2}}
$$

With:

$\mathrm{X}_{\mathrm{i}}=$ observation data (actual data)

$\mathrm{Y}_{\mathrm{i}}=$ estimation data (estimation result data)

$\overline{X_{i}}=$ average observation data

$\mathrm{N}=$ the number of data

Table 1. Criteria of Nash-Sutcliffe Efficiency (NSE) Value

\begin{tabular}{cc}
\hline NSE Value & Interpretation \\
\hline NSE $>0.75$ & Good \\
$0.36<$ NSE $<0.75$ & Qualified \\
NSE $<0.36$ & Not Qualified \\
\hline
\end{tabular}

2. Correlation Coefficient

The purpose of this analysis is to obtain a pattern and closeness relationship between two or more variables.

$$
\mathrm{R}=\frac{N \sum_{i=1}^{N} X_{i} Y i-\sum_{i=1}^{N} X_{i}-\sum_{i=1}^{N} Y i}{\sqrt{N \sum_{i=1}^{N} X_{i}^{2}-\left(\sum_{i=1}^{N} X_{i}\right)^{2}} \sqrt{N \sum_{i=1}^{N} Y_{i}^{2}-\left(\sum_{i=1}^{N} Y_{i}\right)^{2}}} \ldots
$$

With:

$\mathrm{X}_{\mathrm{i}}=$ observation data (actual data)

$\mathrm{Y}_{\mathrm{i}}=$ estimation data (estimation result data)

$\mathrm{N}=$ the number of data

Table 2. Criteria of Correlation Coefficient Value

\begin{tabular}{cc}
\hline R Value & Interpretation \\
\hline $0-0.19$ & Very Low \\
$0.20-0.39$ & Low \\
$0.40-0.59$ & Moderate \\
$0.60-0.79$ & Strong \\
$0.8-1$ & Very Strong \\
\hline
\end{tabular}

3. Root Mean Squared Error (RMSE)

$$
\mathrm{RMSE}=\sqrt{\frac{\sum_{i=1}^{N}\left(X_{i}-Y_{i}\right)^{2}}{N}}
$$

With:

$\mathrm{X}_{\mathrm{i}}=$ observation data (actual data)

$\mathrm{Y}_{\mathrm{i}}=$ estimation data (estimation result data)

$\mathrm{N}=$ the number of data 


\section{Relative Error Test}

This test is used to determine the comparison between the magnitudes of one variable against other variables used as a benchmark for actual variables.

$$
\mathrm{KR}=\frac{\sum_{i=1}^{N}\left(X_{i}-Y_{i}\right)}{Y_{i}} \times 100 \%
$$

With:

$\mathrm{X}_{\mathrm{i}}=$ observation data (actual data)

$\mathrm{Y}_{\mathrm{i}}=$ estimation data (estimation result data)

$\mathrm{N}=$ the number of data

\section{Results and Discussion}

\subsection{Hydrological Analysis}

Consistency Test

Consistency Test is carried out by two methods, the double mass curve method for station post rainfall data and the RAPS method for TRMM data and discharge data

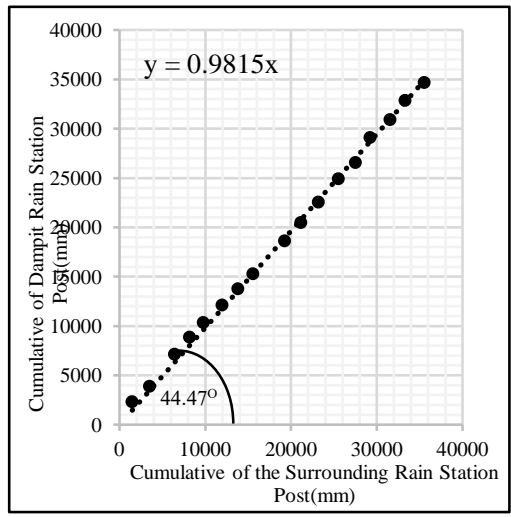

Figure 1 Double Mass Curve of dampit Rain Station Post

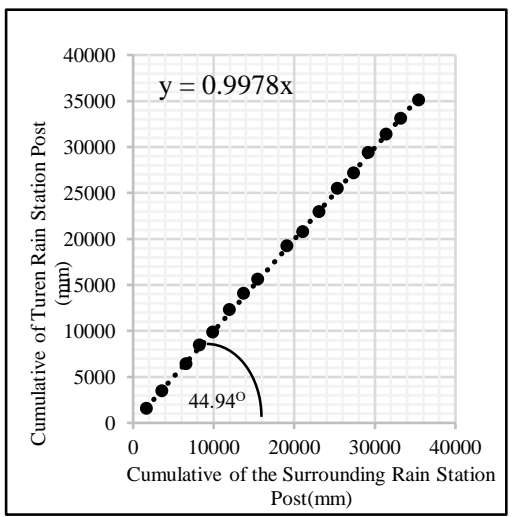

Figure 4 Double Mass Curve of Turen Rain Station Post

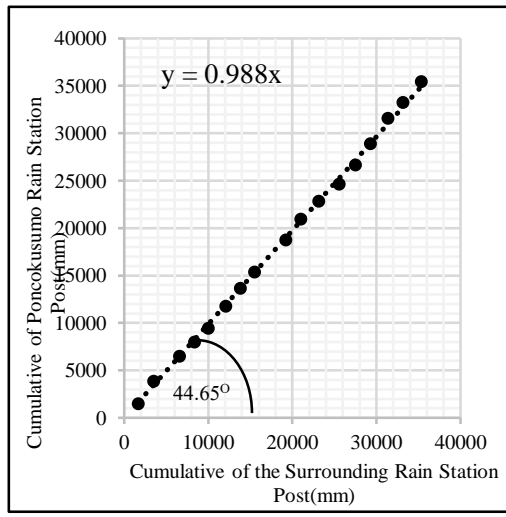

Figure 2 Double Mass Curve of Poncokusumo Rain Station Post

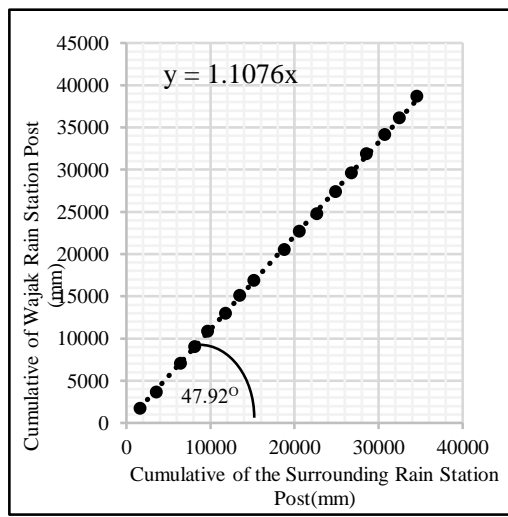

Figure 5 Double Mass Curve of Wajak Rain Station Post

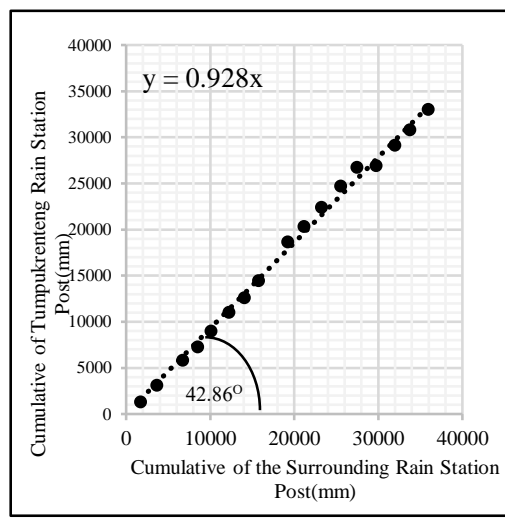

Figure 3 Double Mass Curve of Tumpukrenteng Rain Station Post 
Table 3 Recapitulation of the $\alpha$ value at each rain station post

\begin{tabular}{clc}
\hline No & Rain Station Post & $\alpha$ value \\
\hline 1 & Dampit & $44.47^{\circ}$ \\
2 & Poncokusumo & $44.65^{\circ}$ \\
3 & Tumpukrenteng & $42.86^{\circ}$ \\
4 & Turen & $44.94^{\circ}$ \\
5 & Wajak & $47.92^{\circ}$ \\
\hline
\end{tabular}

Table 4 Recapitulation of Consistency Test Results

\begin{tabular}{cccccccc}
\hline \multirow{2}{*}{ No } & Post Name & $\begin{array}{c}\text { Double Mass } \\
\text { Curve Method }\end{array}$ & \multicolumn{5}{c}{ RAPS Method } \\
\cline { 3 - 7 } & & Angle & $\mathrm{Q} / \mathrm{n}^{0,5}$ calculate & $\mathrm{Q} / \mathrm{n}^{0,5 \text { table }}$ & $\mathrm{R} / \mathrm{n}^{0,5}$ calculate & $\mathrm{R} / \mathrm{n}^{0,5 \text { table }}$ & \\
\hline 1 & Dampit & $44.47^{\circ}$ & - & - & - & - & Consistent \\
2 & Poncokusumo & $44.65^{\circ}$ & - & - & - & - & Consistent \\
3 & Tumpukrenteng & $42.86^{\circ}$ & - & - & - & - & Consistent \\
4 & Turen & $44.94^{\circ}$ & - & - & - & - & Consistent \\
5 & Wajak & $47.92^{\circ}$ & - & - & - & - & Consistent \\
6 & AWLR & - & 0.54 & 1.16 & 0.63 & 1.31 & Consistent \\
7 & TRMM & - & 0.41 & 1.20 & 0.54 & 1.39 & Consistent \\
\hline
\end{tabular}

Based on Figure 1 to Figure 5 and Table 3 then can be said that rainfall data of rain station post that used after being tested using the Double Mass Curve Method is consistent because the resulting angle is in the value ranges of $42^{\circ}<\alpha<48^{\circ}$. Whereas based on Table 4, the TRMM rainfall data consistency test and the discharge data using the RAPS Method also meet the test requirements because the value of $\mathrm{Q}_{\text {calculate }}<\mathrm{Q}_{\text {critical }}$ and the value of $\mathrm{R}_{\text {calculate }}<\mathrm{R}_{\text {critical }}$ so that the results can be considered to be consistent. These test results indicate that the selected data can be used for further hydrological testing and analysis.

\section{Homogeneity Test}

In this study, annual rainfall data of the rainfall station was tested for absence of trends by the Spearman Method using 2-side T-Test. The recapitulation of the test results presented as follows.

Table 5 Recapitulation of Test for No Trend Results

\begin{tabular}{clcccc}
\hline No. & Name of Rain Station Post & $\mathrm{T}_{\text {calculate }}$ & $\alpha$ & $\mathrm{t}_{\mathrm{c}}$ & Information \\
\hline 1 & Dampit & 0.774 & $5 \%$ & 2.131 & not indicate a trend \\
2 & Poncokusumo & 0.754 & $5 \%$ & 2.131 & not indicate a trend \\
3 & Tumpukrenteng & 0.876 & $5 \%$ & 2.131 & not indicate a trend \\
4 & Turen & 0.266 & $5 \%$ & 2.131 & not indicate a trend \\
5 & Wajak & 2.052 & $5 \%$ & 2.131 & not indicate a trend \\
6 & AWLR Tawangrejeni & 2.561 & $1 \%$ & 3.169 & not indicate a trend \\
7 & TRMM & 0.324 & $5 \%$ & 2.131 & not indicate a trend \\
\hline
\end{tabular}

Based on Table 5 can be seen that the entire data (except AWLR discharge data) did not indicate a trend by showing $t_{\text {calculate }}<t_{\text {table }}$ at a $5 \%$ confidence degree. Thus, these data can be further analyzed. 
Table 6 Recapitulation of Variance Stability Test Results (F Test)

\begin{tabular}{clcccl}
\hline No. & Name of Rain Station Post & $\mathrm{F}_{\text {calculate }}$ & $\alpha$ & $\mathrm{F}_{\mathrm{c}}$ & Information \\
\hline 1 & Dampit & 0.759 & $5 \%$ & 3.370 & The value of the variance is stable \\
2 & Poncokusumo & 1.168 & $5 \%$ & 3.370 & The value of the variance is stable \\
3 & Tumpukrenteng & 5.658 & $1 \%$ & 6.840 & The value of the variance is stable \\
4 & Turen & 1.449 & $5 \%$ & 3.370 & The value of the variance is stable \\
5 & Wajak & 0.830 & $5 \%$ & 3.370 & The value of the variance is stable \\
6 & AWLR Tawangrejeni & 22.326 & $1 \%$ & 10.97 & The value of the variance is not stable \\
7 & TRMM & 1.416 & $5 \%$ & 3.370 & The value of the variance is stable \\
\hline
\end{tabular}

Table 7 Recapitulation of Average Stability Test Results (t Test) Annual Period

\begin{tabular}{clcccc}
\hline No. & Name of Rain Station Post & $\mathrm{T}_{\text {calculate }}$ & $\alpha$ & $\mathrm{t}_{\mathrm{c}}$ & Information \\
\hline 1 & Dampit & 0.856 & $5 \%$ & 2.131 & The average value is stable \\
2 & Poncokusumo & 1.190 & $5 \%$ & 2.131 & The average value is stable \\
3 & Tumpukrenteng & 0.617 & $5 \%$ & 2.131 & The average value is stable \\
4 & Turen & 0.727 & $5 \%$ & 2.131 & The average value is stable \\
5 & Wajak & 1.183 & $5 \%$ & 2.131 & The average value is stable \\
6 & AWLR Tawangrejeni & 1.906 & $5 \%$ & 2.228 & The average value is stable \\
7 & TRMM & -0.129 & $5 \%$ & 2.131 & The average value is stable \\
\hline
\end{tabular}

From Table 6 and Table 7 above it can be seen that the value of $F$ calculate $<$ the value of $F$ table and the value of $t$ calculate $<$ the value of $t$ table, so it can be concluded that the rainfall data of the five rain station posts, the TRMM rainfall data, and the discharge data used have a stable variance and average. The persistence test is an independent test for each value in the periodic series. First, the number of serial correlation coefficients must be calculated by the Spearman Method, then the calculation of the persistence test with the T-Test is conducted. The recapitulation of the test results is presented as follows.

Table 8 Recapitulation of Persistence Test Results

\begin{tabular}{clcccc}
\hline No. & Name of Rain Station Post & $\mathrm{T}_{\text {calculate }}$ & $\alpha$ & $\mathrm{t}_{\mathrm{c}}$ & Information \\
\hline 1 & Dampit & -1.65 & $5 \%$ & 2.145 & Data is random \\
2 & Turen & -1.432 & $5 \%$ & 2.145 & Data is random \\
3 & Tumpakrenteng & -2.028 & $5 \%$ & 2.145 & Data is random \\
4 & Wajak & -3.840 & $5 \%$ & 2.145 & Data is random \\
5 & Poncokusumo & -0.828 & $5 \%$ & 2.145 & Data is random \\
4 & Tawangrenjani AWLR Discharge & -0.178 & $5 \%$ & 2.262 & Data is random \\
5 & TRMM & -0.793 & $5 \%$ & 2.145 & Data is random \\
\hline
\end{tabular}

Based on Table 8 it can be seen that almost all of the data are random by showing $t_{\text {calculate }}<t_{\text {table }}$ at $5 \%$ confidence level/degree. Thus, these data can be analyzed further.

\subsection{Correlation of Rain Data of Rain Station Post and TRMM}

Based on Table 9, the correlation analysis results of all rain station posts with TRMM data (20022018 data), have a good correlation with TRMM rain data, this can be seen from the correlation coefficient values that are at values $>0,6$. 
Table 9 Correlation Results of Monthly Rain Data of Rain Post with TRMM

\begin{tabular}{clc}
\hline No. & \multicolumn{1}{c}{ Post } & Correlation \\
\hline 1 & Dampit & 0.81 \\
2 & Poncokusumo & 0.81 \\
3 & Tumpuk Renteng & 0.78 \\
4 & Turen & 0.86 \\
5 & Wajak & 0.85 \\
\hline
\end{tabular}

Table 10 Thiessen coefficient of Lesti Sub Watershed

\begin{tabular}{clcc}
\hline No. & \multicolumn{1}{c}{ Post } & Area $\left(\mathrm{km}^{2}\right)$ & $\mathrm{Kr}$ \\
\hline 1 & Dampit & 200.601 & 0.659 \\
2 & Poncokusumo & 89.476 & 0.294 \\
3 & Tumpuk Renteng & 1.299 & 0.004 \\
4 & Turen & 12.937 & 0.043 \\
5 & Wajak & 76.894 & 0.253 \\
\hline \multicolumn{4}{c}{ Total } \\
\hline
\end{tabular}

\subsection{Regional Average Rainfall Analysis}

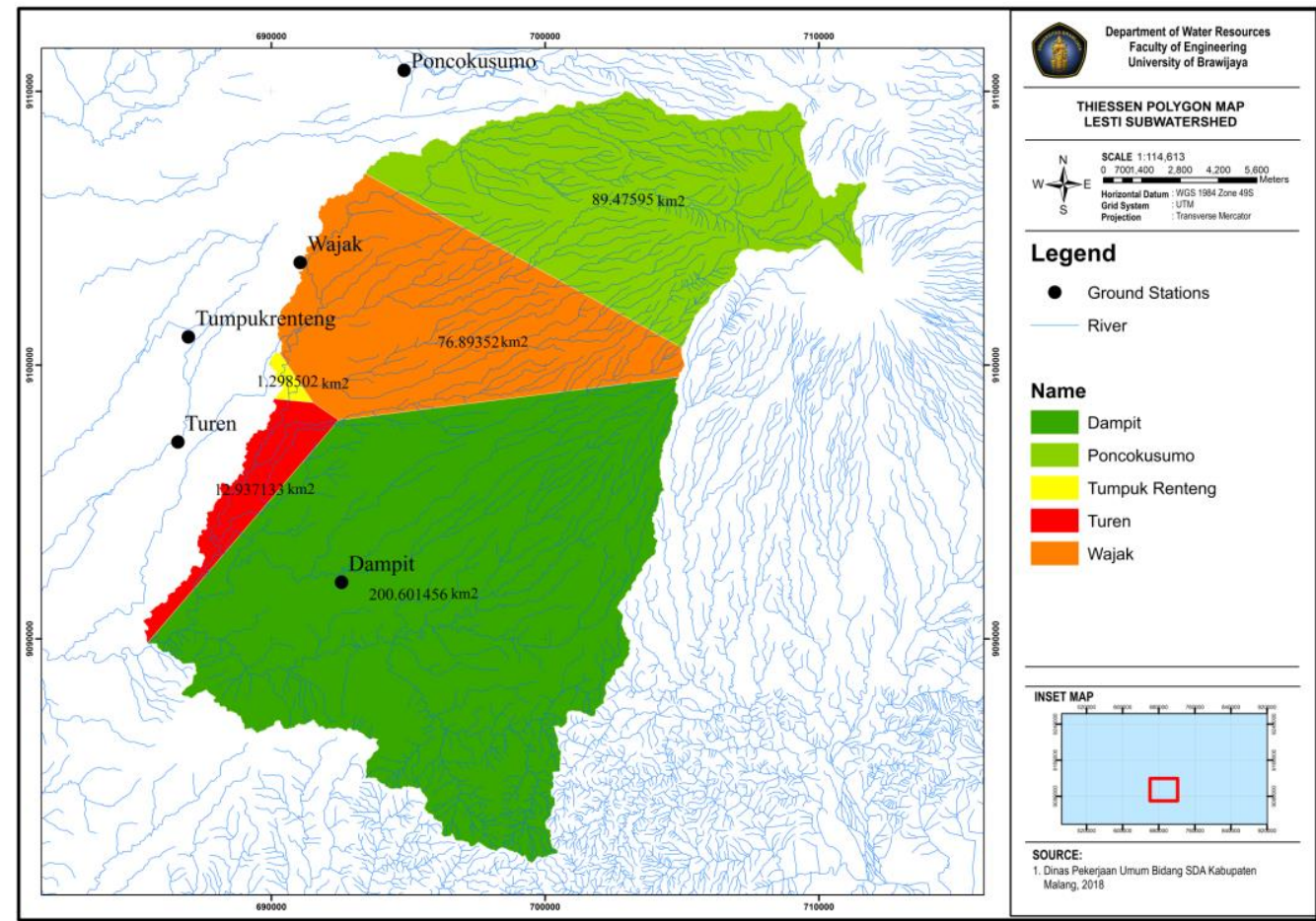

Figure 6 Map of the Influence Area of the Lesti Sub Watershed Rain Station Post by using the Thiessen Polygon Method

Based on Table 10 obtained that the results of the value of $\mathrm{Kr}$ for each post of the rain station is a comparison of the area of influence of each post of the rain station on the area of the Lesti Sub Watershed towards the total area of the Lesti Sub Watershed. The calculation results of the $\mathrm{Kr}$ value are then used to calculate the regional average rainfall. 
Figure 7 shows a comparison graph of regional average rainfall with TRMM before being corrected. From the graph it can be seen that the TRMM rainfall value tends to be smaller, but has a pattern and fluctuation that is almost the same as the regional average rainfall. Further analysis after obtaining regional average rainfall is a validation analysis of rainfall data from the rain station post and TRMM rainfall.

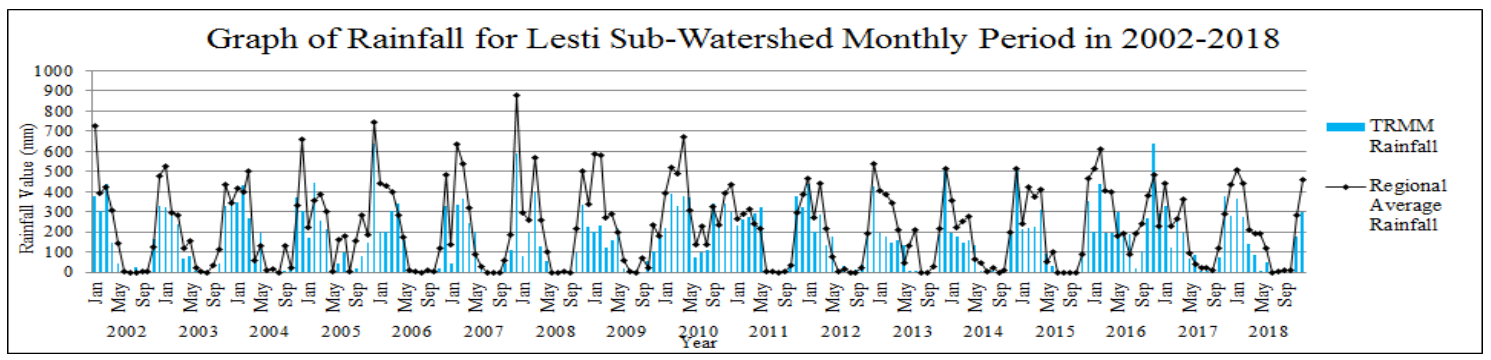

Figure 7 Graph of comparison of average regional rainfall with TRMM

\subsection{Calibration and Validation Analysis of Rain Data from Rain Station Post and TRMM}

\section{TRMM Rain Data Calibration}

Figure 8 through Figure 13 shows the calibration scatterplot to get the best equation. From the regression equation that has been obtained to get the corrected TRMM rain data then the used regression equation with the largest $\mathrm{R}^{2}$ value. Obtained the results of the TRMM rainfall regression equation in the Lesti watershed with $\mathrm{R}^{2}=0.7158$ with the polynomial equation.

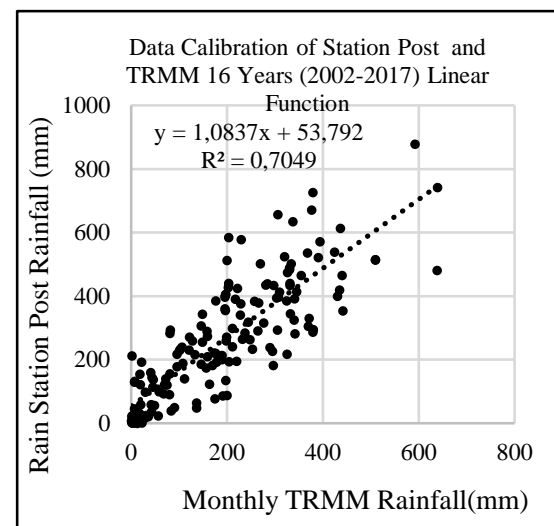

Figure 8 Linear Regression Equation

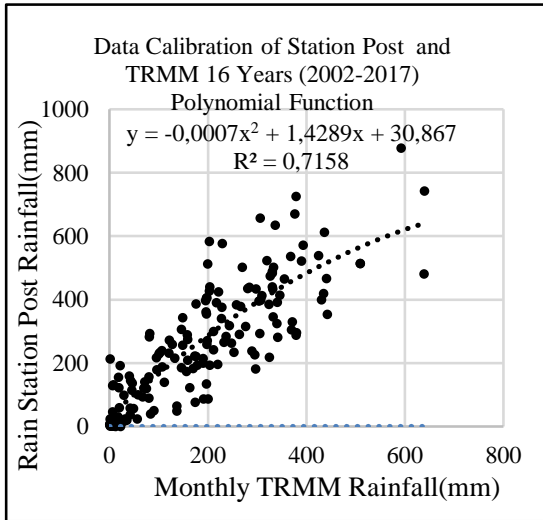

Figure 10 Polynomial Regression Equation

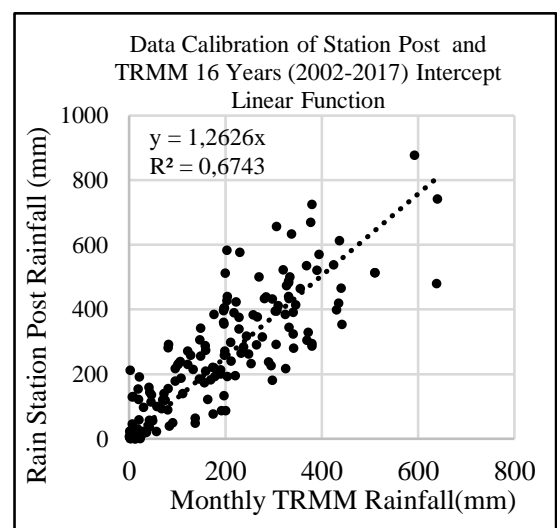

Figure 9 Intercept Linear Regression Equation

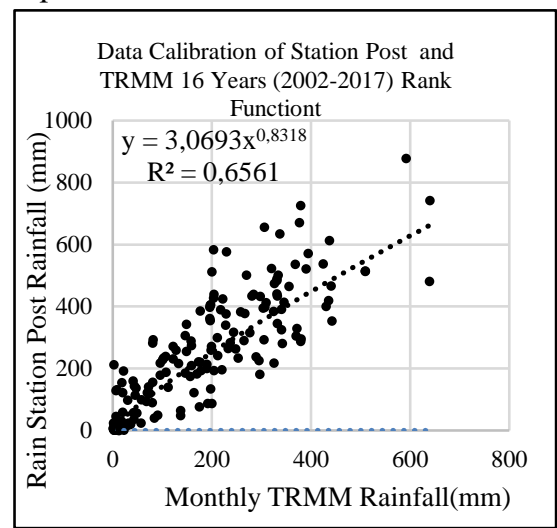

Figure 11 Rank Regression Equation 


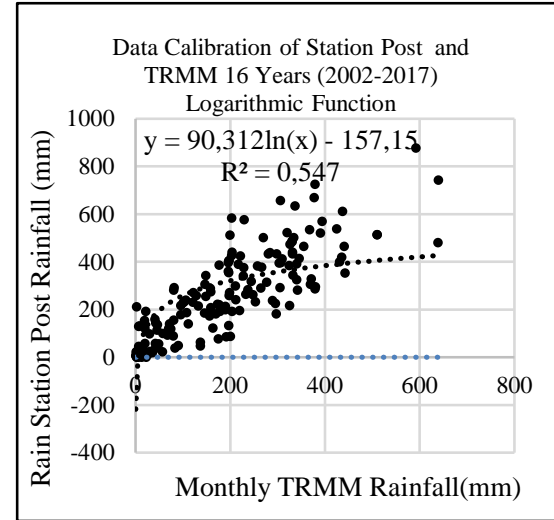

Figure 12 Logarithmic Regression Equation

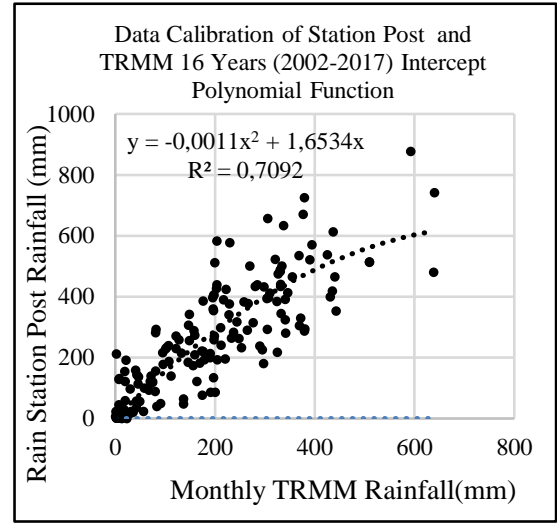

Figure 13 Intercept Polynomial Regression Equation

TRMM Rain Data Verification

The next stage is verification of the data outside the data used for calibration.

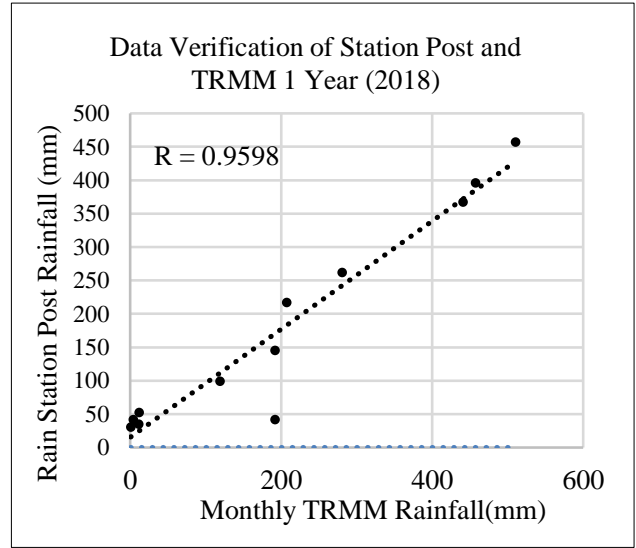

Figure 14 Verification of TRMM Rainfall in 2018

Figure 14 shows a verification graph of rain data of rain station post with TRMM outside the calibration year. The correlation value (R) produced for the 2018 regional rainfall is $95,98 \%$, this shows that the corrected TRMM rainfall data has a very strong correlation with station post rainfall data.

\section{TRMM Rain Data Validation}

Validation is performed on data outside the data used for calibration. To be able to measure the magnitude of the difference in the results of the model calculation towards the observational data then conducted TRMM rain data validation using the objective function of the NSE (Nash-Sutcliffe Efficiency), Correlation Coefficient (R), RMSE (Root Mean Square Error), and Relative Error (RE).

Table 11 Recapitulation of Calculation Results for Validation of Station Post Rainfall Data with TRMM Before Corrected

\begin{tabular}{cccccccc}
\hline \multicolumn{2}{c}{ Total Year } & \multicolumn{2}{c}{ NSE } & \multirow{2}{*}{ RMSE } & \multirow{2}{*}{ KR } & & \multicolumn{2}{c}{ R } \\
\cline { 1 - 3 } Calibration & Validation & Value & Interpretation & & & Value & Interpretation \\
\hline 10 & 7 & 0.545 & Qualified & 114.949 & 0.269 & 0.829 & Strong \\
13 & 4 & 0.476 & Qualified & 122.960 & 0.282 & 0.807 & Moderate \\
16 & 1 & 0.631 & Qualified & 108.479 & 0.416 & 0.959 & Very Strong \\
\hline
\end{tabular}


Table 12 Recapitulation of Calculation Results for Validation of Station Post Rainfall Data with

TRMM After Corrected

\begin{tabular}{cccccccc}
\hline \multicolumn{2}{c}{ Total Year } & \multicolumn{2}{c}{ NSE } & \multirow{2}{*}{ RMSE } & \multirow{2}{*}{ KR } & \multicolumn{2}{c}{ R } \\
\cline { 1 - 2 } \cline { 6 - 8 } Calibration & Validation & Value & Interpretation & & & Value & Interpretation \\
\hline 10 & 7 & 0.657 & Qualified & 99.726 & 0.045 & 0.835 & Strong \\
13 & 4 & 0.674 & Qualified & 97.033 & 0.007 & 0.825 & Medium \\
16 & 1 & 0.890 & Good & 59.163 & 0.116 & 0.960 & Very Strong \\
\hline
\end{tabular}

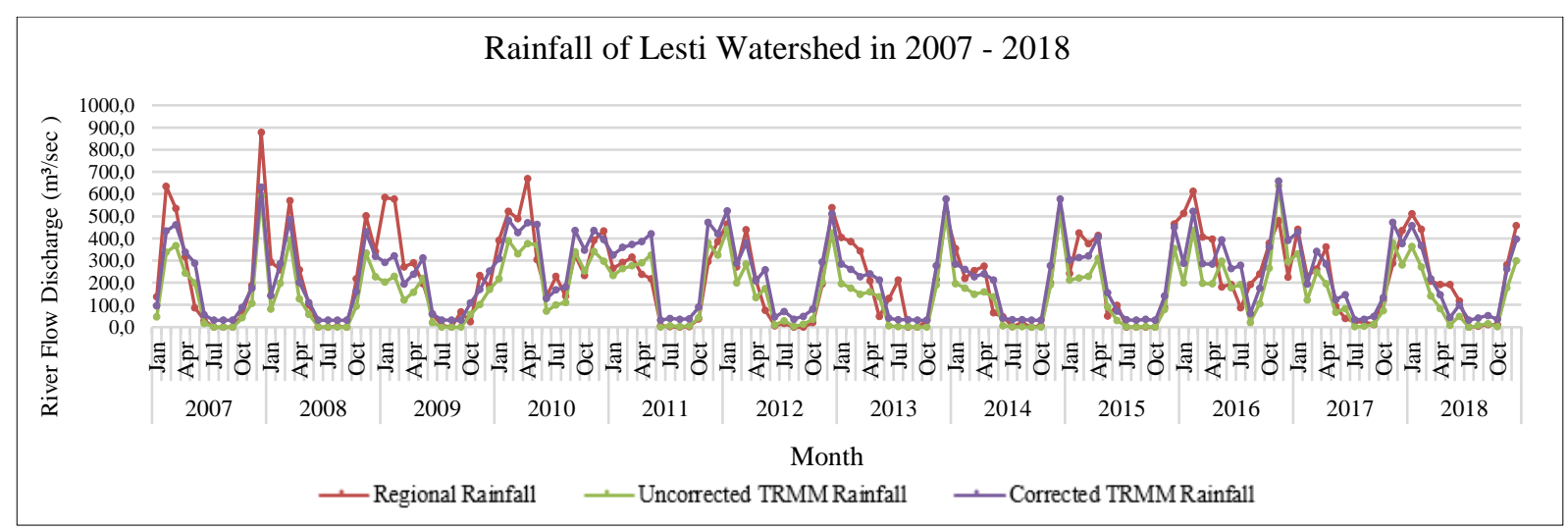

Figure 15 Graph of Lesti Watershed Rainfall in 2007-2018

Based on Table 11 and Table 12 by comparing the validation results of uncorrected data and corrected data, the corrected data validation results have better results. The results of the data validation show the results "Qualified" at the NSE method for all data, except for 1 year validation of the corrected data obtained the results of "Good".

The RMSE value for uncorrected data validation is relatively high, but has decreased in the validation of corrected data. The value of Relative Error is classified as very small in all data. For the Correlation Coefficient of all data, the calculation results show a very strong relationship, but the best results are found in the validation of 1-year corrected data using 16-year data calibration. This shows that the more data used for calibration, then the better it is for validation.

\subsection{Water Discharge Analysis FJ Mock Methode}

Flow discharge simulation is carried out by trial and error of parameter values which are carried out repeatedly until it meets the model performance criteria. Based on the calibration results obtained, the simulation discharge hydrograph approaches the observation discharge. The trial results of the parameter values can be seen in Table 13 .

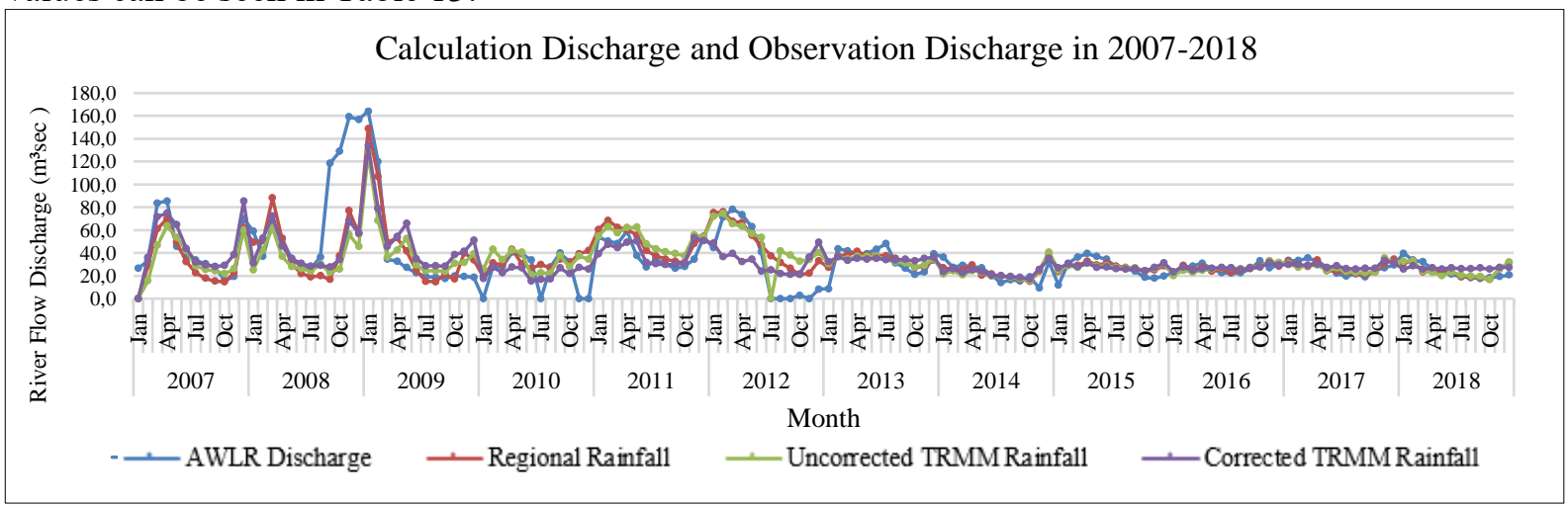

Figure 16 Graph of Model Discharge and Observation Discharge of Lesti Watershed in 2002-2018 
Table 13 Simulation Results for FJ Mock Parameters

\begin{tabular}{ccccccc}
\hline \multirow{2}{*}{ No } & \multirow{2}{*}{ Year } & \multicolumn{5}{c}{ Parameter } \\
\cline { 3 - 7 } & & SMC $(\mathrm{mm})$ & $\mathrm{i}$ & $\mathrm{k}$ & $\mathrm{IS}(\mathrm{mm})$ & $\mathrm{Vn}(\mathrm{mm})$ \\
\hline 1 & 2007 & 250 & 0.53 & 0.09 & 50 & 50 \\
2 & 2008 & 250 & 0.21 & 0.92 & 50 & 50 \\
3 & 2009 & 250 & 0.08 & 0.10 & 50 & 50 \\
4 & 2010 & 250 & 0.72 & 0.99 & 50 & 50 \\
5 & 2011 & 250 & 0.61 & 0.97 & 50 & 50 \\
6 & 2012 & 250 & 0.56 & 0.99 & 50 & 50 \\
7 & 2013 & 250 & 0.97 & 0.97 & 50 & 50 \\
8 & 2014 & 250 & 0.79 & 0.99 & 50 & 50 \\
9 & 2015 & 250 & 0.91 & 0.99 & 50 & 50 \\
10 & 2016 & 250 & 0.95 & 0.99 & 50 & 50 \\
11 & 2017 & 250 & 0.89 & 0.99 & 50 & 50 \\
12 & 2018 & 250 & 0.98 & 0.99 & 50 & 50 \\
\hline
\end{tabular}

From Figure 16 it can be seen that the trend of monthly AWLR discharge and the FJ Mock Method flow discharge have almost the same pattern. From the table, it appears that the AWLR data for 20082009 is indeed that the value is very far from the average each year which occurs every season.

\section{Validation of F.J. Mock Flow Discharge}

To show the accuracy value of each flow discharge simulation from the different rain database with the FJ Mock Method, conducted validation test of observation Mock discharge data (AWLR) using the objective function of NSE, Correlation Coefficient, RMSE and Relative Error.

Table 14 Validation Results on FJ Mock Flow Discharge

\begin{tabular}{clcccc}
\hline \multirow{2}{*}{ No } & \multirow{2}{*}{ Discharge of Model Results with database } & \multicolumn{4}{c}{ Value } \\
\cline { 3 - 6 } & & NSE & R & RMSE & KR \\
\hline 1 & Rain Station Post Rainfall & 0.507 & 0.713 & 19.383 & 0.001 \\
2 & TRMM Rainfall & 0.374 & 0.614 & 21.839 & 0.016 \\
3 & Corrected TRMM Rainfall & 0.411 & 0.646 & 21.190 & 0.025 \\
\hline
\end{tabular}

Based on Table 14 above, the NSE value of the model discharge with three variations of rain data has a value $>0.36$ which indicates that the discharge analysis of the model result can be said qualified. But the NSE value of discharge data with TRMM database has the smallest value, so that it is better to use corrected TRMM data. While the value of the correlation coefficient (R) from the three sources of rain data has a value of $0,5<\mathrm{R} \leq 0,75$ which indicates that the results of the model have a strong correlation. The RMSE value of the model discharge with the rain data of rain station post is smaller than the discharge of TRMM model result and corrected TRMM, it shows that the discharge with the rain station post data has a smaller deviation than the AWLR discharge. The relative error value (RE) of the model discharge with TRMM rain data has a smaller value than the other results, this shows that the model discharge with TRMM rain data there is less error. The error here refers to errors in recording.

\section{Conclusions}

The results of correlation analysis of TRMM satellite rainfall data and rainfall data from the rain station post have a good. The results of the station post rainfall data validation with TRMM show that the results of the corrected data validation have better results than the TRMM data before being corrected. The best result is found in the validation of 1-year corrected data using 16-year data 
calibration. This shows that the more data used for calibration, then the better it is for validation. The results of the validation towards the analysis of flow discharge using the FJ Mock Method, validation is obtained by flow discharge analysis using rainfall data of the rain station post, overall analysis shows TRMM data can be used as an alternative of the rain data that is used to estimate flow discharge, but the result of flow discharge analysis is still better using rainfall data from the rain station post.

\section{References}

[1] Cheng Chen. 2011. Adaptability Evaluation of TRMM Satellite Rainfall and Its Application in the Dongjiang River Basin. Elsevier Procedia Environmental Sciences 10 ( 2011 ) 396 - 402.

[2] Destiana WP, Joko S, Adam P. 2017. Evaluasi Data Hujan Satelit Untuk Prediksi Data Hujan Pengamatan Menggunakan Cross Correlation. Seminar Nasional Sains dan Teknologi

[3] Levina. 2016. Comparison of TRMM satellite rainfall and APHRODITE for drought analysis in the Pemali-Comal River Basin. Elsevier Procedia Environmental Sciences 33 ( 2016 ) 187 195.

[4] Maulidani, S. Ihsan, N., Sulistiawaty. 2015. Analisis Pola dan Intensitas Curah Hujan Berdasarkan Data Observasi dan Satelit Tropical Rainfall Measuring Mission (TRMM) 3B42 V7 di Makasar. Jurnal Sains dan Pendidikan Fisika, Vol. 11, No.1

[5] Motovilov, Y.G., Gottschalk, L., Engeland, K. dan Rodhe, A. 1999. Validation of a Distributed Hydrological Model Against Spatial Observations. Elsevier Agricultural and Forest Meteorology. $98: 257-277$.

[6] Na Yang. 2017. Evaluation of the TRMM multisatellite precipitation analysis and its applicability in supporting reservoir operation and water resources management in Hanjiang basin, China. Elsevier Journal of Hydrology 549 (2017) 313-325.

[7] Sugiyono. 2017. Matematika : Aproksimasi Kesalahan. Modul. Tidak diterbitkan. Yogyakarta: Universitas Gadjah Mada

[8] Syaifullah, D. 2013. Kondisi Curah Hujan Pada Kejadian Banjir Jakarta dan Analisis Kondisi Udara atas Wilayah Jakarta Bulan Januari-Februari 2013. Jurnal Sains dan Teknologi Modifikasi Cuaca (JSTMC), 14(1), 19-26

[9] Syaifullah, D. 2014. Validasi Data TRMM terhadap Data Curah Hujan Aktual di Tiga DAS di Indonesia. Jurnal Meteorologi dan Geofisika 15 (2) :109-118. 